\title{
Effect of Blanching Media on the Yield Stress of Green Leafy Vegetable Puree
}

\author{
Jagamohan Meher, R Kannan, Rajnandini Meher
}

\begin{abstract}
This study was carried out to determine the effect of different blanching media on the rheological value (yield stress) of two indigenous leafy vegetables, Ipomea aquatic and Basella alba puree. They were blanched using three different blanching media ( $\mathrm{NaCl}, \mathrm{MgO}$, and $\mathrm{NaCl}+\mathrm{MgO}$ ) for 3 minutes at a temperature of $90^{\circ} \mathrm{C}$. The yield stress of vegetable puree $\left(3.5^{\circ} \mathrm{Brix}\right)$ was investigated by varying shear rate from 0.1 to $100 / \mathrm{s}$ at different temperatures (278K and $358 \mathrm{~K})$ for both unblanched and blanched samples (with media). Measurements and calculations of the different yield stress of puree were performed by MCR-102 and Casson model respectively. The blanch samples were generally of higher yield stress than the unblanched samples with respect to blanching media and temperature. One-way ANOVA indicated a significant difference in yield stress between the two vegetables across the various blanching media $(p<0.05)$. Basella alba had an overall higher yield stress value than another leafy vegetable with respect to different blanching media and temperatures.
\end{abstract}

Keywords: Yield stress; leafy vegetables; puree; temperature

\section{INTRODUCTION}

India has a rich heritage of flora and fauna due to its varied climate, which is suitable for the growth of different species of leafy vegetables. In India, around 800 species are selected as wild palatable plants over the country (Wild palatable plants give nourishment amount as well as make a critical commitment to the populace sustenance consistently $[1,2]$. There is so many very popular traditional leafy vegetable like Borhaavia difusa, Basell Rubra, Amaranthus species, Cleome gynandra, Corchorus species, Chenopodium species, Leucas cephalotes, Trianthema portulacastrum, and Hibiscus cannabinus, are widely available in the communities during the rainy season. They are readily available on the local market during the season, however, limited during the offseason. Wild plants such as Ipomoea aquatic and Basella alba are very popular and are widely available in India. Green leafy vegetables are the most nutritious vegetables as compared to other vegetables and it is the source of iron, calcium, potassium, beta carotene, vitamin-c, folic acid and riboflavin[3]. They are high in fiber, incredibly low in fat and starches, and a rich source of good protein. Green leafy vegetables can expect an important activity in reducing micronutrient needs. Furthermore, the

Revised Manuscript Received on December 05, 2019.

* Correspondence Author

Jagamohan Meher*,Dept. of Agricultural Engineering, School of Agriculture and Processing Sciences, Kalasalingam Academy of Research Education, Sriviliputhur,Tamil Nadu, India. Email: jaga@klu.ac.in

R Kannan, Dept. of Agriculture, School of Agriculture and Processing Sciences, Kalasalingam Academy of Research Education, Sriviliputhur,Tamil Nadu, India. Email: kannan@klu.ac.in

Rajanandini Meher , Department of Biotechnology, Kalasalingam Academy of Research Education, Sriviliputhur,Tamil Nadu, India. Email: rajanandinimeher256@gmail.com diversity in vegetable species offer collection in family diet and add to family food security as well as dietary grouped assortment. Further, it gives financial support to nuclear families through the sell in their nearby market.

Regardless of the huge use of the leaves in regions of vegetable development, the utilization of the leaves has been constrained within seven days of the harvesting in view of its perishability nature. Most of the research on these leaves so far has concentrated on the nutritional properties of the leaves but less research work has been done to enhance the nutritional value to leaves. Value Minimally processing of these leafy vegetables into the form of puree or paste, increase their utilization in a different hotel, restaurant, and food eateries [5].

Purees are concentrated scatterings of insoluble matter in fluid media, which can be set up by crushing, processing or sieving the consumable piece of cooked organic product or vegetable. The fruit or vegetable is exposed to cooking (blanching) for around four to five minutes before mixing utilizing a kitchen machine (blender)[6]. Most of the vegetables and fruit have been processed into purees. Despite crude material or processing, purees are wanted when they have consistent characteristics[7]. The handling conditions in the assembling of numerous items influence the last item characteristics. Thermal processing and the mixing of stabilizers have been appeared to influence the last nature of purees. There is less enhancement in the utilization of these leaves and no documentation is accessible on the yield stress leaf puree created utilizing various salts during blanching.

Yield stress is the amount of pressure required to initiate the flow of the fluid layer from one above another [5]. In terms of strength, it is defined as the amount of force required for the breakdown of linkage connecting the fluid flow or the coherent molecular structure of a fluid sample[6,8].

The minimally processing of these leaves into puree would exhibit the leaves in an elective structure for use and achieve simplicity of handling. The research work would give the best preparing conditions for acquiring these leaf purees with its yield stress. Thus, the principal targets of the present finding were (1) to measure and correlate the yield stress of two distinctive vegetable puree types obtained by utilizing three rheological models, and (2) to analyze the impact of sample temperature and salts concentration on the yield stresses value.

\section{MATERIALS AND METHODS}

\section{A. SAMPLE PREPARATION}

Fresh wild edible leaves were gathered and recognized by the Agriculture Department of Indira Gandhi Krishi Vidyalaya(IGKV), Raipur and washed with running water to dispose of residue and particles. The leaves were then washed in the vinegar solution 
and after that shredded to thin cuts utilizing blades. Every species of leaves was about $1.2 \mathrm{~kg}$ in weight was taken for the handling. This is isolated into four segments of $300 \mathrm{~g}$ each. One portion filled in as the unblanched test and the rest as treated as a blanched sample.

\section{B. HOT WATER BLANCHING:}

A known part of leaves was blanched utilizing different blanching media $(\mathrm{MgO}, \mathrm{MgO}+\mathrm{NaCl}, \mathrm{NaCl}$, and $\mathrm{Raw})$ for 3 mins at a temperature of $363 \mathrm{~K}$. The blanching was done in a pan, where the leaves are dipped in hot water(363K) for a duration of 3 mins. After blanching the blanched leaves were immediately chilled into cold water to stop the degradation of nutrient content and color. Chilled leaves were ground by utilizing wet grounder with subsequent using an extra quantity of water for smooth grinding. After grinding, the ground material is passed through a Whatman filter paper $(125 \mathrm{~mm})$. Adequacy of blanching(time) of these leaves is checked by the peroxidase inactivity test. In this test, $5 \mathrm{ml}$ concentrate was taken in a test cylinder containing $1 \mathrm{ml}$ guaiacol solution $(0.5$ $\%$ in ethanol) and $1 \mathrm{ml}$ hydrogen peroxide $(0.03 \%)$. If there is no air bubble formation and color changes in samples. The Blanching was considered to have been achieved in the consequent samples.

\section{PUREE MAKING:}

Utilizing a Panasonic blender processor, each of the samples was pureed for 2 mins at power level 3. The required quantity of water was added to the prepared puree until it achieves the TSS level of 3.50 Brix. Then the samples were kept in $400 \mathrm{ml}$ glass containers.

\section{RHEOLOGICAL MEASUREMENTS}

Rheometer MCR 102 (Anton Paar, GmbH, Germany) with a mounted four-bladed vane geometry ST22-4V-40 were utilized for all rheological analysis. The geometry attached to Rheometer was exactly pull down vertically downward, unto a distance of $10 \mathrm{~mm}$ from the surface level[4]. Then, $35 \mathrm{ml}$ of the sample was poured in a $40 \mathrm{ml}$ capacity of the Rheometer cup and the temperature of the cup was kept up at $303 \mathrm{~K}$. As most of the rheological analysis performed for different Non -Newtonian food samples at shear ranges of 0.1-100 $\mathrm{s}^{-1}$.[9]. So, we performed our rheological analysis for 100 data points at an interim of $3 \mathrm{~s}$. Tests were permitted to relax for $5 \mathrm{~min}$ before leading rheological estimations. The Rheoplus programming of Anton Paar $\mathrm{GmbH}$ is utilized for all the rheological estimations in triplicate as endorsed by [10]. In this way, Data were fitted to the Hershel-Bulkley (1), Casson (2) and Bingham (3) models[6]. Herschel-Bulkley, Casson and Bingham yield stresses were acquired separately by extrapolation of shear rate-shear stress information as indicated by flow models (1)- (3).

Herschel-Bulkley $\tau=\tau_{0 H}+K_{H}(\gamma)^{n}$

Casson $\tau^{0.5}=K_{O C}+K_{c}(\gamma)^{0.5}$

Bingham $\tau=\tau_{0 B}+\eta \gamma$

Where: $\tau$ (Shear Stress, $\mathrm{Pa}), \gamma$ (Shear rate, $\mathrm{s}^{-1}$ ), $\mathrm{K}$ (Consistency index, Pa.s), n(Behavior index, dimensionless), $\mathrm{Koc}($ Initial shear stress of the Casson model, $\mathrm{Pa}$ ), $\mathrm{Kc}(\mathrm{Casson}$ plastic viscosity, Pa.s) and $\tau$ (Initial shear stress, $\mathrm{Pa}$ ).
Every single measurable examination and rheological model fitting were performed utilizing software (Origin Pro 9.1; Origin Lab Corporation, Northampton, MA, USA). Means were determined by utilizing Fisher's least significant (LSD). All the results are determined at a 5\% significance level. Statistical examination and rheological model fitting were performed utilizing Origin Pro 9.1. Means were determined to utilize Fisher's least critical contrast (LSD) methodology. Significance was characterized at the 5\% level. The accuracy of the models was determined by considering the R2 and RMSE value utilizing the below mentioned Eq. (4, 5) [11].

$$
\begin{aligned}
& S S E=\sum_{i=1}^{n}\left(Y_{\text {exp }, i}-Y_{\text {pred }, i}\right)^{2} \\
& R M S E=\sqrt{\frac{S S E}{n m}}
\end{aligned}
$$

Where $\mathrm{m}$ and $\mathrm{n}$ are a number of constants and observation number in the corresponding model.

\section{RESULTS AND DISCUSSION}

The steady-state flow curves of Ipomoea aquatic and Basella alba puree (TSS $=3.5{ }^{0}$ Brix) at a temperature $(278$ $\& 358 \mathrm{~K}$ ) for $1-100 \mathrm{~s}^{-1}$ (shear rate range) are shown in Fig (1-4). As expected $(n<1)$, means the puree showed a shear-thinning behavior with having yield stress. The yield stress is the minimum shear stress necessary to start the fluid flow, being correlated to the material's inner composition, which ought to be broken[9]. However, the food sample is behaving like an elastic solid, when the stress level is less than from its yield stress value. Similarly, it behaving like a viscous liquid when its yield stress is more than the stress. The occurrence of yield stress is a distinctive quality of multiphase materials, like fruit juices and pulps, which are produced by diffusion of insoluble components in water solution (soluble polysaccharides, serum, minerals, sugars, and proteins). The obtained data were fitted to three nonNewtonian models namely Bingham law, Casson and Herschel-Buckley model (Eqs. (1, 2 \& 3)).

The best scientific models for depicting the flow behavior of purees was chosen dependent on the coefficient of determination $\left(\mathrm{R}^{2}\right)$, RMSEs, the presence of yield stress and by and large predisposition factors acquired during the fitting (Table 1 and 2). Even though the two models fit adequately, however, the temperature range analyzed and the $R^{2}$ value was observed to be more prominent than 0.97 however while thinking about the parameter (yield stress), Casson model was proper to portray the rheological behavior of the puree. The findings on coriander and mint leaf puree propose that acquired estimations of yield stress, consistency coefficient $(\mathrm{K})$ and flow behavior (n) for vegetable items could satisfactorily depict the flow behavior of puree. 


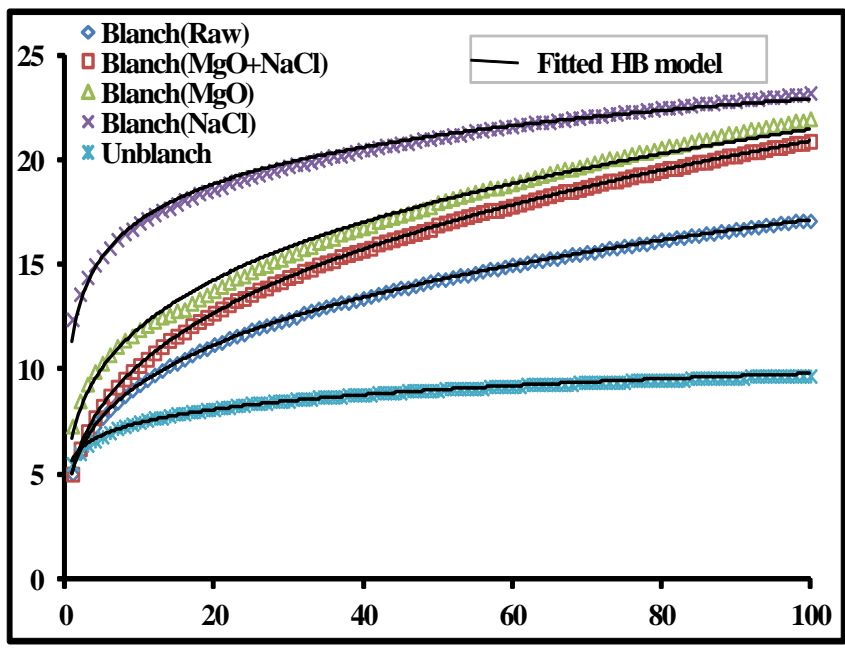

Fig.1 Rheogram of Ipomoea Aquatica leaves( $\left.3.5{ }^{0} \mathrm{Brix}\right)$ at $278 \mathrm{~K}$

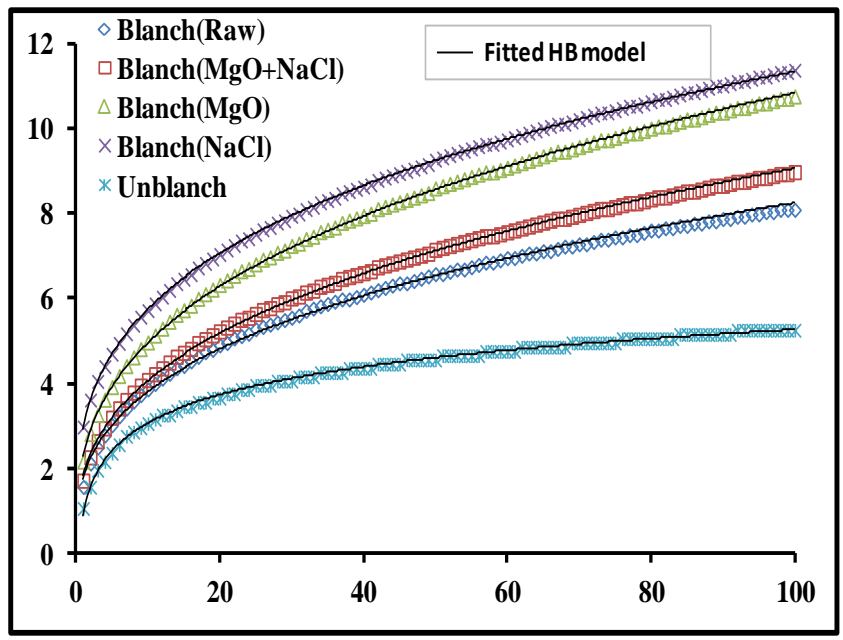

Fig.2 Rheogram of Ipomoea Aquatica leaves ( $3.5^{0} \mathrm{Brix}$ ) at $318 \mathrm{~K}$

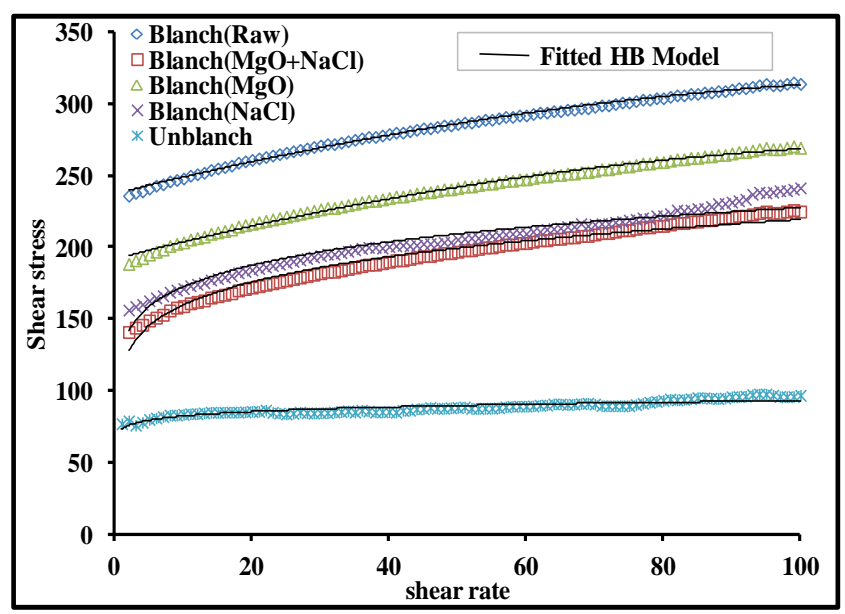

Fig.3 Rheogram of Basella alba leaves puree( $\left.3.5^{0} \mathrm{Brix}\right)$ at $278 \mathrm{~K}$

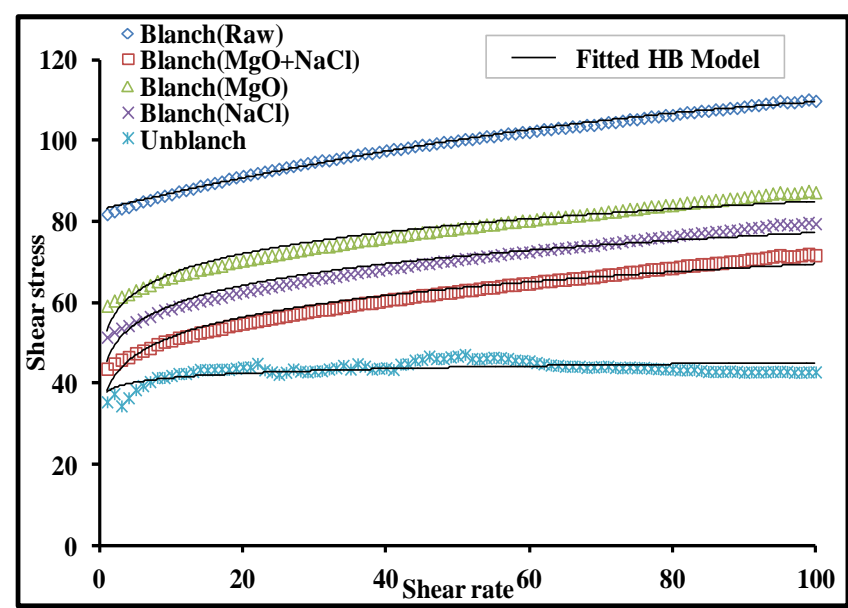

Fig.4 Rheogram of Basella alba leaves puree $\left(3.5^{0} \mathrm{Brix}\right)$ at 318K

\section{A. INFLUENCE OF PROCESSING TEMPERATURE ON THE YIELD STRESS OF LEAFY PUREE}

Tables (1 and 2), showed the yield stress data obtained by fitting with different models to both fresh and blanched vegetable puree (Ipomea aquatic and Basella alba) media contains various salts or without salts. The yield stress obtained at $278 \mathrm{~K}$, for both blanched with salts and blanched sample without salts shows that, blanched media with salts having higher yield stress as compared to the blanched sample without salt. With respect to other processing temperature also shows the same trends of yield value. Blanch $(\mathrm{NaCl})$ sample shows higher yield stress as compared to Blanch $(\mathrm{MgO})$ and $\mathrm{Blanch}(\mathrm{MgO}+\mathrm{NaCl})$ in both the leafy vegetable purees with respect to various temperatures(Table 1 and 2). The yield stress values of all the samples decrease with an increase in temperature. The reason behind this decrease may be due to the structural breakdown of the puree structure with increasing temperature and the puree showing more fluidity. Increasing fluidity means decreasing in yield value. All the vegetable purees are showing non-linear behavior and the different models are fitted well with the rheological parameters. But the correlation coefficients of the fits to the HB model is higher as compared to Casson and Bingham models with respect to temperatures.

As expected from the flow curves (Fig. 1-3) of different puree samples, by fitting with different models used, the HB Models fits well with the highest correlation coefficients for both blanched with or without salt samples. Which was indicating that nonlinear models are more suitable for characterization of vegetable purees flow behavior? From the fitted data, it was observed that $\tau_{\mathrm{OH}}$ is higher for the puree samples having salt as compared to sample without salt, indicating that by adding salt to the puree sample led to the formation of complex aggregated structure.

\section{B. INFLUENCE OF BLANCHED AND UNBLANCHED SAMPLE ON THE YIELD STRESS OF LEAFY PUREE}

The rheological data for unblanched samples of both 
Effect of Blanching Media on the Yield Stress of Green Leafy Vegetable Puree

Table 1. Effect of different levels of temperatures on Power-law, Heschel-Buckley \& Casson model fitted to the data of $3.8{ }^{0} \mathrm{Brix}$ Ipomoea aquatic leaves puree

\begin{tabular}{|c|c|c|c|c|c|c|c|}
\hline Sample & Parameters & \multicolumn{2}{|c|}{ Bingham } & \multicolumn{2}{|c|}{ Herschel Buckley } & \multicolumn{2}{|c|}{ Casson } \\
\hline \multirow[t]{6}{*}{ Blanch(Raw) } & Temperatures & $278 \mathrm{~K}$ & $358 \mathrm{~K}$ & $278 \mathrm{~K}$ & $358 \mathrm{~K}$ & $278 \mathrm{~K}$ & $358 \mathrm{~K}$ \\
\hline & $\sigma_{0}(\mathrm{~Pa})$ & - & & 3.85 & 0.851 & 17.777 & 7.300 \\
\hline & $\mathrm{n}$ & 0.266 & 0.323 & 0.266 & 0.336 & - & - \\
\hline & $\mathrm{K}\left(\mathrm{Pa} \cdot \mathrm{s}^{\mathrm{n}}\right)$ & 5.030 & 1.843 & 5.029 & 1.7517 & 0.374 & 0.202 \\
\hline & $\mathrm{R}^{2}$ & 0.990 & 0.970 & 0.990 & 0.970 & 0.970 & 0.980 \\
\hline & RMSE & 2.541 & 3.145 & 2.541 & 3.145 & 3.360 & 0.188 \\
\hline \multirow[t]{5}{*}{ Blanch $(\mathrm{MgO}+\mathrm{NaCl})$} & $\sigma_{0}(\mathrm{~Pa})$ & - & - & 4.2 & 0.892 & 19.347 & 7.687 \\
\hline & $\mathrm{n}$ & 0.310 & 0.341 & 0.309 & 0.3484 & - & - \\
\hline & $\mathrm{K}\left(\mathrm{Pa} \cdot \mathrm{s}^{\mathrm{n}}\right)$ & 5.015 & 1.875 & 5.035 & 1.820 & 0.504 & 0.231 \\
\hline & $\mathrm{R}^{2}$ & 0.97 & 0.97 & 0.97 & 0.96 & 0.99 & 0.95 \\
\hline & RMSE & 0.006 & 0.006 & 0.056 & 0.006 & - & 0.198 \\
\hline \multirow[t]{5}{*}{ Blanch $(\mathrm{MgO})$} & $\sigma_{0}(\mathrm{~Pa})$ & - & - & 6.45 & 1.56 & 22.320 & 9.371 \\
\hline & $\mathrm{n}$ & 0.272 & 0.335 & 0.310 & 0.34 & - & - \\
\hline & $\mathrm{K}\left(\mathrm{Pa} \cdot \mathrm{s}^{\mathrm{n}}\right)$ & 6.220 & 2.312 & 6.688 & 2.264 & 0.480 & 0.273 \\
\hline & $\mathrm{R}^{2}$ & 0.97 & 0.96 & 0.97 & 0.97 & 0.97 & 0.98 \\
\hline & RMSE & 0.056 & 0.006 & 0.006 & 0.006 & 0.343 & 0.235 \\
\hline \multirow[t]{5}{*}{ Blanch $(\mathrm{NaCl})$} & $\sigma_{0}(\mathrm{~Pa})$ & - & - & 11.15 & 2.3 & 33.331 & 10.881 \\
\hline & $\mathrm{n}$ & 0.135 & 0.297 & 0.315 & 0.295 & - & - \\
\hline & $\mathrm{K}\left(\mathrm{Pa} \cdot \mathrm{s}^{\mathrm{n}}\right)$ & 12.421 & 2.893 & 12.41 & 2.915 & 0.301 & 0.267 \\
\hline & $\mathrm{R}^{2}$ & 0.97 & 0.95 & 0.97 & 0.95 & 0.95 & 0.99 \\
\hline & RMSE & 0.010 & 0.004 & 0.010 & 0.004 & 0.353 & - \\
\hline
\end{tabular}

Table 2. Effect of different levels of temperatures on Power-law, Heschel-Buckley \& Casson model fitted to the data of $3.8{ }^{0}$ Brix Basella alba leaves puree

\begin{tabular}{|c|c|c|c|c|c|c|c|}
\hline \multirow[t]{2}{*}{ Sample } & Parameters & \multicolumn{2}{|c|}{ Bingham } & \multicolumn{2}{|c|}{ Herschel-Buckley } & \multicolumn{2}{|c|}{ Casson } \\
\hline & Temperatures & $278 \mathrm{~K}$ & $\begin{array}{l}358 \\
\mathrm{~K}\end{array}$ & $278 \mathrm{~K}$ & $358 \mathrm{~K}$ & $278 \mathrm{~K}$ & $358 \mathrm{~K}$ \\
\hline \multirow[t]{5}{*}{ Blanch(Raw) } & $\sigma_{0}(\mathrm{~Pa})$ & - & - & 223.727 & 78.919 & 188.523 & 171.248 \\
\hline & $\mathrm{n}$ & 0.112 & 0.088 & 0.557 & 0.576 & - & - \\
\hline & $\mathrm{K}\left(\mathrm{Pa} . \mathrm{s}^{\mathrm{n}}\right)$ & 186.062 & 71.536 & 7.040 & 2.215 & 3.060 & 1.061 \\
\hline & $\mathrm{R}^{2}$ & 0.95 & 0.98 & 0.97 & 0.96 & 0.95 & 0.99 \\
\hline & RMSE & 1.514 & 0.683 & 0.695 & 0.167 & 1.467 & 0.018 \\
\hline \multirow[t]{5}{*}{ Blanch $(\mathrm{MgO}+\mathrm{NaCl})$} & $\sigma_{0}(\mathrm{~Pa})$ & - & - & 128.696 & 40.382 & 307.628 & 98.479 \\
\hline & $\mathrm{n}$ & 0.166 & 0.140 & 0.507 & 0.490 & - & - \\
\hline & $\mathrm{K}\left(\mathrm{Pa} \cdot \mathrm{s}^{\mathrm{n}}\right)$ & 104.019 & 36.769 & 9.421 & 3.312 & 3.150 & 0.990 \\
\hline & $\mathrm{R}^{2}$ & 0.99 & 0.96 & 0.98 & 0.98 & 0.97 & 0.95 \\
\hline & RMSE & 1.006 & 0.413 & 0.309 & 0.169 & 1.827 & 0.020 \\
\hline \multirow[t]{5}{*}{ Blanch(MgO) } & $\sigma_{0}(\mathrm{~Pa})$ & - & - & 176.176 & 55.961 & 398.094 & 129.637 \\
\hline & $\mathrm{n}$ & 0.134 & 0.109 & 0.530 & 0.490 & - & - \\
\hline & $\mathrm{K}\left(\mathrm{Pa} . \mathrm{s}^{\mathrm{n}}\right)$ & 144.352 & 51.727 & 8.204 & 3.312 & 3.104 & 0.990 \\
\hline & $\mathrm{R}^{2}$ & 0.95 & 0.99 & 0.96 & 0.98 & 0.98 & 0.95 \\
\hline & RMSE & 1.275 & 0.485 & 0.726 & 0.169 & 1.640 & 0.020 \\
\hline \multirow[t]{5}{*}{ Blanch $(\mathrm{NaCl})$} & $\sigma_{0}(\mathrm{~Pa})$ & - & - & 154.903 & 48.171 & 332.547 & 114.058 \\
\hline & $\mathrm{n}$ & 0.123 & 0.123 & 0.678 & 0.490 & - & - \\
\hline & $\mathrm{K}\left(\mathrm{Pa} . \mathrm{s}^{\mathrm{n}}\right)$ & 129.724 & 44.208 & 3.603 & 3.312 & 2.980 & 0.990 \\
\hline & $\mathrm{R}^{2}$ & 0.96 & 0.98 & 0.95 & 0.97 & 0.98 & 0.97 \\
\hline & RMSE & 1.789 & 0.453 & 0.469 & 0.169 & 1.560 & 0.020 \\
\hline
\end{tabular}


International Journal of Recent Technology and Engineering (IJRTE) ISSN: 2277-3878, Volume-8 Issue-4S2, December 2019

Table 3. Effect of different levels of temperatures on Bingham, Heschel-Buckley \& Casson model fitted to the data of $3.8{ }^{0}$ Brix of two different unblanched leaves puree

\begin{tabular}{|c|c|c|c|c|c|c|c|}
\hline \multirow[t]{2}{*}{ Sample } & Parameters & \multicolumn{2}{|c|}{ Bingham } & \multicolumn{2}{|c|}{ Herschel-Buckley } & \multicolumn{2}{|l|}{ Casson } \\
\hline & Temperatures & $278 \mathrm{~K}$ & $358 \mathrm{~K}$ & $278 \mathrm{~K}$ & $358 \mathrm{~K}$ & $278 \mathrm{~K}$ & $358 \mathrm{~K}$ \\
\hline \multirow{5}{*}{$\begin{array}{l}\text { Unblanch } \\
\text { (Ipomea } \\
\text { aqutica) }\end{array}$} & $\sigma_{0}(\mathrm{~Pa})$ & - & - & 20.005 & 15.560 & 14.762 & 5.872 \\
\hline & $\mathrm{n}$ & 0.117 & 0.250 & 0.040 & 0.040 & - & - \\
\hline & $\mathrm{K}\left(\mathrm{Pa} \cdot \mathrm{s}^{\mathrm{n}}\right)$ & 5.711 & 1.709 & 20.998 & 20.998 & 0.111 & 0.111 \\
\hline & $\mathrm{R}^{2}$ & 0.87 & 0.97 & 0.96 & 0.95 & 0.99 & 0.99 \\
\hline & RMSE & 0.016 & 0.027 & 3.341 & 3.342 & - & 0.152 \\
\hline \multirow{5}{*}{$\begin{array}{l}\text { Unblanch } \\
\text { (Basella alba) }\end{array}$} & $\sigma_{0}(\mathrm{~Pa})$ & - & - & 80.800 & 45.557 & 160.586 & 84.578 \\
\hline & $\mathrm{n}$ & 0.055 & 0.035 & 0.098 & -0.554 & - & - \\
\hline & $\mathrm{K}\left(\mathrm{Pa} \cdot \mathrm{s}^{\mathrm{n}}\right)$ & $\begin{array}{ll} & 72.18 \\
8 & \end{array}$ & 38.314 & 1.102 & -12.555 & 0.638 & 0.101 \\
\hline & $\mathrm{R}^{2}$ & 0.97 & 0.97 & 0.96 & 0.95 & 0.99 & 0.95 \\
\hline & RMSE & 0.798 & 0.616 & 0.046 & 1.078 & 0.567 & - \\
\hline
\end{tabular}

leafy vegetable puree is shown in Table. 3. The yield stress of both the leafy vegetable purees is decreased with respect to incrementing in temperatures from $278 \mathrm{~K}$ to $358 \mathrm{~K}$. Processing parameters like temperature, solid concentration of the puree are greatly affected the rheological properties of the puree[12]. The yield stress value obtained for the unblanched puree sample of Ipomoea aquatic and Basella alba was 20.005 and $80.800 \mathrm{~Pa}$ at a temperature of $278 \mathrm{~K}$ respectively. With increasing temperature, the value decreases to 15.560 and 45.526 $\mathrm{Pa}$ for Ipomoea aquatic and Basella alba respectively. Among both blanched and unblanched puree samples, Basella alba puree is having a nearly higher yield value than Ipomoea aquatic and in both blanch and unblanched case. Higher yield stress values indicate puree that is more consistent. Fluids that are more viscous have higher yield stress[13]. However, the blanch of the sample was more viscous than the unblanched and the values obtained for the yield stress of blanch samples were significantly different at $\mathrm{p}<0.05$, with a blanched puree of higher yield stress as compared to unblanched puree. The different samples used [blanched and unblanched] could explain the varying yield stress of the leafy vegetable purees. The yield stress of the vegetable puree mainly depends upon the particle size, methods used for obtaining the puree and temperature during the rheological analysis of variety of fruit or vegetable being used Similar types of findings are also obtained previously in case of different leafy vegetables $[8,14]$.

\section{EFFECT OF THE BLANCHED SAMPLE WITH SALT MEDIA MGO, MGO+NACL, NACL) ON THE YIELD STRESS OF LEAFY PUREE}

Rheological analysis of the blanched (TSS $=4.5{ }^{0}$ Brix) with $\mathrm{NaCl}+\mathrm{MgO}$ at a temperature of $278 \mathrm{~K}$ results in yield value of Ipomoea aquatic and Basella alba puree are 19.347 \& 307.628, respectively. The unblanched puree results in lower yield value than blanched one during the rheological analysis at both temperatures $(278 \& 358 \mathrm{~K})$ in all cases of leafy vegetables. The addition of salts a) $\mathrm{NaCl}$ b) $\mathrm{MgO}$ and other salts $(\mathrm{MgO}+\mathrm{NaCl})$ in the blanching container, results in higher Yield stress. Yield values for a blanched puree with salts of $\mathrm{MgO}+\mathrm{NaCl}, \mathrm{MgO}$ and $\mathrm{NaCl}$, with quenching in cold water results in values to be $294.328,252.128$ and 124.437 for Hibiscus sabdariffa pure at $278 \mathrm{~K}$, respectively. Blanch raw sample without any salts with Coldwater dip results in lower yield stress value as compared to cold water + $\mathrm{NaCl}$ and cold water + other salts $(\mathrm{MgO}+\mathrm{NaCl})$; The maximum yield value was observed in the case of blanching media containing $\mathrm{MgO}+\mathrm{NaCl}$. As, food purees, for the most part, fill in as a polyelectrolyte and react with salts contained in food (Zobel 1984). These interactions may cause changes in rheological characters and the biological properties of the purees. However, all the vegetable puree remained shear thinning, regardless of salt type and concentration. Such a behavior has been found in Ocimum basilicum seed gum (Salehi and Kashaninejad 2015). The blanching treatments also caused a significant $(\mathrm{p}<0.05)$ increase in the yield values of leaves with blanching media than the raw sample treatment. Blanching treatments generally affect heat-labile components of foods such as fiber, minerals, carbohydrates, which may change the properties of food during cooking[9]. These are some of the contributing factors in yield rise of the leaves. Blanched samples destroyed some heat-labile components leading to a decrease in yield stress but blanching with media in the leaves thus leading to an increase in yield value. 
Rheological studied on Opuntia ficus indica mucilage gum showed that the change in viscosity is less in presence of $\mathrm{Na}^{+}$and $\mathrm{K}^{+}$ions as compared to $\mathrm{Ca}^{2+}$ and $\mathrm{Mg}^{2+}$ ions in mucilage gum[15]. Also during the addition of $\mathrm{NaCl}$ during blanching, lowering the heat penetration (thermal conductivity) as compared to other types of salts used. As the $\mathrm{NaCl}$ salts are commonly used in our daily cooking process, hence, its addition in our puree sample could not result in many changes in viscosity value as compared to other types of salts. Another reason behind using $\mathrm{NaCl}$ salts in our puree sample is that other types of salt may sometime cause tarter taste, while $\mathrm{NaCl}$ does not. Tarter taste makes the puree unacceptable for the consumer's tongue and hence $\mathrm{NaCl}$ is the best option to add in puree sample to enhance the flavor and taste of the puree.

\section{CONCLUSIONS}

The experimental data obtained from the rheological analysis of both the leafy vegetables puree (either blanched /unblanched) was best fitted by the Herschel Buckley model, as compared to all other models. As the yield stress data obtained by using the Herschel-Bulkley model is consistent and more reliable as compare to Bingham and Casson models. The yield stress obtained during analysis with varying salts concentration and sample temperatures for different puree samples is comparable. The processing temperature has a greater effect on the yield stress of the vegetable puree as compare to salt concentration. During processing, the yield stress of all the vegetable puree increase with the increase in salt concentration, showing greater strength. However, with increasing sample temperature during processing, yield stresses decreased with processing, indicating a weaker structure of puree.

\section{REFERENCES}

1. Singh H. B., Arora R. K. 1978: Wild edible plants of India 1st ed. ICAR Publication, New Delhi. p 88 .1978.

2. Ogle Britta M., Ho Thi Tuyet, Hoang Nghia Duyet and Nguyen Nhut Xuan Dung.: Food, Feed or Medicine: The multiple functions of edible wild plants in Vietnam, Econ. Bot. 571:103-117. 2003.

3. Gopalan, C. R. B. V., BV Rama Sastri, and S. C. Balasubramanian. Nutritive value of Indian foods. National Institute of Nutrition, Indian Council of Medical Research, 1989.

4. Steffe, J.F. "Yield stress: phenomena and measurement", in Advances in Food Engineering, ed. Singh R.P.; Wirakartakusmah A, CRC Press, Boca Ratón, FL, USA,(1992a), 363-376.

5. A. Massa, C. González, A. Maestro, J. Labanda, and A. Ibarz, (2010). Rheological characterization of peach purees. Journal of texture studies, 41(4), 532-548.

6. Alvarado, J. D. D., \& Romero, C. H. (1989). Physical properties of fruits I. density and viscosity of juices as functions of soluble solids content and temperature. Latin American Applied Research, 19(15), 15-21.

7. Koocheki A, Razavi SM, Milani E, Moghadam TM, Abedini M, Alamatiyan S, Izadkhah S. Physical properties of watermelon seed as a function of moisture content and variety. International Agrophysics. 2007 Dec 12;21(4):349.

8. Sun A, Gunasekaran S. Yield stress in foods: measurements and applications. International Journal of Food Properties. 2009 Jan 1;12(1):70-101.

9. Tabilo-Munizaga G, Barbosa-Cánovas GV. Rheology for the food industry. Journal of food engineering. 2005 Mar 1;67(1-2):147-56.

10. Rao MA, Rizvi SS, Datta AK, Ahmed J. Engineering properties of foods. CRC press; 2014 Apr 22.

11. Rao MA. Flow and functional models for rheological properties of fluid foods. InRheology of fluid, semisolid, and solid foods 2014 (pp. 27-61). Springer, Boston, MA.

12. 12 Constenla DT, Lozano JE, Crapiste GH. Thermophysical properties of clarified apple juice as a function of concentration and temperature. Journal of Food Science. 1989 May;54(3):663-8.
13. Cepeda E, Villaran MC. Density and viscosity of Malus floribunda juice as a function of concentration and temperature. Journal of Food Engineering. 1999 Aug 1;41(2):103-7.

14. Bayod E, Månsson $\mathrm{P}$, Innings F, Bergenståhl B, Tornberg E. Low shear rheology of concentrated tomato products. Effect of particle size and time. Food Biophysics. 2007 Dec 1;2(4):146-57.

15. Medina-Torres L, Brito-De La Fuente E, Torrestiana-Sanchez B, Katthain R. Rheological properties of the mucilage gum (Opuntia ficus indica). Food hydrocolloids. 2000 Sep 1;14(5):417-24. 